\title{
Municipal Law Enforcement Officers: towards a new system of local policing in the Netherlands?
}

\section{Ronald van Steden}

To cite this article: Ronald van Steden (2017) Municipal Law Enforcement Officers: towards a new system of local policing in the Netherlands?, Policing and Society, 27:1, 40-53, DOI: 10.1080/10439463.2015.1017494

To link to this article: http://dx.doi.org/10.1080/10439463.2015.1017494

册 Published online: 09 Mar 2015.

Submit your article to this journal $\widetilde{ }$

Џll Article views: 581

Q View related articles 5

View Crossmark data $־$ 


\title{
Municipal Law Enforcement Officers: towards a new system of local policing in the Netherlands?
}

\author{
Ronald van Steden* \\ Political Science and Public Administration Department, Faculty of Social Sciences, VU University, \\ Amsterdam, The Netherlands
}

(Received 13 June 2014; accepted 5 February 2015)

\begin{abstract}
Since the early 2000s, Dutch city councils have sought to professionalise City Wardens (Stadswachten), transforming them into Municipal Law Enforcement Officers (MLEOs). MLEOs, who hold limited police powers, are now regarded as 'Special Investigative Officers' (Buitengewoon Opsporingsambtenaren - BOAs) and are mostly appointed to supervise local neighbourhoods and town centres. Compared to Police Community Support Officers (PCSOs, who are lower-rank police officials) and private (or commercial) security guards, MLEOs are a different type of 'plural' or 'auxiliary' policing agents, employed by the municipal authorities. This paper explores why MLEOs have become so popular in the Netherlands; the practice and practicalities of municipal policing; and whether the Dutch police will maintain their central position in a highly fragmented system of local security governance. The underlying purpose here is to reflect on the particularities of auxiliary policing in a non-English-speaking nation.
\end{abstract}

Keywords: police auxiliaries; plural policing; municipal law enforcers

\section{Introduction}

A major debate in contemporary criminology concerns the growth of a wide variety of agents and agencies that conduct patrols and engage in law enforcement, crime prevention and criminal investigation in the name of policies to combat crime and disorder (e.g. Buerger and Mazerolle 1998, Loader 2000, Crawford et al. 2005, Jones and Newburn 2006, McLaughlin 2007, Ayling et al. 2009, Terpstra et al. 2013). In particular, scholarly attention has been devoted to the arrival of 'plural' or 'auxiliary' bodies, such as Police Community Support Officers (PCSOs; Johnston 2003) within assorted forces, and the emergence of commercial (Noaks 2000) and, to a lesser degree, community-based (Donnelly 2008) policing initiatives beyond the traditional criminal justice apparatus. Such bodies may be in quite fierce competition with each other. PSCOs have even been introduced in response to an impending 'Balkanization' scenario (Johnston 2007) as British municipalities, and boroughs have started to set up their own private security schemes. Specifically, Sir Ian Blair, the former Commissioner of the Metropolitan Police, has expressed his concerns about the police losing their pivotal position in public order and crime control.

\footnotetext{
*Email: r.van.steden@vu.nl 
The present paper introduces yet another member of the expanding 'police extended family' (Johnston 2003, 2005, 2007), focusing on Municipal Law Enforcement Officers (MLEOs) in the Netherlands. The trends and predicaments surrounding the rise of MLEOs exhibit parallels with what is known from the literature on plural policing in the Anglo-Saxon world. However, the findings and insights presented here also underline the need to extend scholarship to continental Europe. Today's police and policing studies suffer acutely from North American, Australian and British 'ethnocentrism' (Manning 2005 , p. 32) by more or less equating plural police models with the 'privatisation of policing' and the countervailing policy of employing PCSOs to conduct visible public patrols on the streets. In contrast to these two examples, as their designation indicates, MLEOs are a type of municipally based 'quasi-policing' (Jason-Lloyd 2003) body, sworn-in to issue fines to people for 'minor' nuisance and antisocial behaviour. The recognition of the importance of the street work conducted by MLEOs makes it possible to add to the existing body of knowledge about either PCSOs or private security guards who carry out auxiliary policing activities.

The questions posed in the following pages concern how the growing popularity of MLEOs in the Netherlands can be explained; what the practices and practicalities of municipal policing are; and in what ways their position impinges on the sustainability of the police's central role in the maintenance of public order. In answering these questions, the paper explores how the new MLEO function is currently presenting challenges at the local level of 'security governance' (Johnston and Shearing 2003), which have an effect on police forces with whom they need to build enduring and effective working relationships. MLEOs are municipal 'street-level' professionals (Lipsky 1980), and as such they tend to shed a new light on the dynamics between the police and auxiliary officers, which appear distinctly different from their counterparts in the UK and elsewhere. Before going into detail, the following section sketches the methodology on which the empirical research carried out on MLEOs in the Netherlands is based.

\section{Research methodology}

This paper draws on the findings of two distinct yet interrelated studies of the rise and functioning of Dutch MLEOs. The first study presents a panoramic survey of the expansion of municipal policing across the country, local policies towards MLEOs and the challenges they pose to the governance of security. This study rests on six interviews with representatives of MLEO organisations at the municipal level (Van Steden 2012). Second, MLEOs featured in an ethnographic study of their everyday practices in Amsterdam, the capital city of the Netherlands. In total, interviews were held with 15 MLEOs, 3 team leaders and 2 managers concerning their daily work and collaboration with other partners, most notably the police, coupled with 170 hours of participatory observations and informal chats on the streets (Van Steden and Bron 2012). Written documentation and open sources such as websites provided background information to our fieldwork. Furthermore, information was drawn from in-depth studies by other social scientists who looked at what MLEOs do in larger cities (Rekenkamer Rotterdamse 2012, Willemse et al. 2013, Eikenaar and Van Stokkom 2014) and smaller towns (Bervoets et al. 2013) throughout the Netherlands. It was found that ample data are available for use in a review of the presence of MLEOs in the Dutch public domain. 


\section{From City Wardens to municipal law enforcers}

Seen from an historical perspective, MLEOs are the direct successors of City Wardens (Stadswachten). These City Wardens were launched in the late 1980s, a period when theories of 'situational crime prevention' started to top the Dutch political agenda (Van Andel 1989). City Wardens were uniformed agents of social control operating in urban localities. In contrast to the MLEOs, they had no special powers beyond those of the average citizen. Great reliance was thus placed on their social and communicative skills. The popularity of situational crime prevention programmes at that time rested on the belief that opportunity made the thief, not personal or social circumstances. Hence, bringing 'capable guardians' (Cohen and Felson 1979) onto the streets would reduce crime, disorder and feelings of insecurity. Another sentiment expressed in the early Dutch crime and disorder policies was that processes that condoned antisocial (youth) behaviour while at the same time reducing the natural (or informal) social controls by parents, teachers and neighbours had gone too far. City Wardens were thus expected to contribute to an increasing disciplinary élan, supporting the regaining of public order in society.

In addition to these objectives, crime prevention 'was linked to measures to reduce unemployment' (Hofstra and Shapland 1997, p. 266). In other words, City Wardens were recruited from the long-term unemployed with the dual goal of giving people a new purpose in life and putting 'extra eyes and ears' on the street. Underlying this policy was a strongly felt need to implement reintegration programmes from which City Wardens could be recruited without bearing the stigma of 'a pure employment project' (Hauber et al. 1996, p. 217). Hofstra and Shapland describe City Wardens as follows:

The central activity of Stadswachten is daytime patrolling of city centres, though, [...] [in-] creasingly they are being used at night [...]. The wardens are expected to aid the public [...] and are seen as 'ambassadors of the city'. They are also expected to assist in preventing crime and in controlling nuisance behaviour, as well as providing a reassuring presence. [...] If there is an outbreak of some kind of criminal behaviour, the wardens can immediately notify the police. [...] The aim is that Stadswachten should not only be a direct resource for shoppers and tourists [...], but also increase the quality of life in the city centre and so make the public feel safe there. It is hoped that this will increase the numbers of people using city centres, make them more lively places, and hence increase trade for shopkeepers and for the city. (1997, p. 268)

It can be argued that MLEOs are a kind of 'Stadswachten 2.0'. Granting them special powers means they represent a wave of professionalisation in longer-term Dutch public safety policies. MLEOs can be seen as a more mature version of the previously established City Wardens, who had no special powers at all.

In judicial terms, MLEOs were born out of a larger system of Special Investigative Officers (Buitengewoon Opsporingsambtenaren - BOAs), which was introduced during a major police reform in 1993. It is important to realise that the BOA - the legal, sworn-in category within which MLEOs fall - includes many more functions and functionaries than the MLEOs alone. Among other examples, BOAs embrace 'low-level' police staff who work at police station front desks, do administrative work and file felony complaints; railway masters and inspectors who supervise trains, trams, metros and buses in search of free riders; and game wardens who patrol nature reserves to catch poachers and forestall illegal waste dumping. Under strict conditions and on a small scale, it is even possible for private security companies to 'hire out' BOAs to their customers, most notably 
municipalities (Terpstra 2012). There are about 25,000 BOAs in the Netherlands, of whom, at a minimum, 4000 are employed as MLEOs.

The Dutch government revised the BOA system in 2010 in response to a 'severe fragmentation of the special investigation function over time, and the corresponding sharp rise in the number of occupations carrying special investigative authority' (Mein and Hartman 2013, p. 75). Earlier, in 2007, the Ministry of Justice had already introduced a single badge to be worn on the uniform, the goal being to avoid any confusion the citizenry may have had about the judicial mandate of the authorities they encounter (Merrit 2009). Shortly after that, and more fundamentally, the ministry decided to restructure the byzantine way in which Special Investigation Officers were legally organised. The solution found was to designate a system of six separate legal spheres (public domain, environmental issues, school and education, public transport, welfare and social support, and other), each corresponding to restricted areas of expertise and regulation concerning the exercise of powers, the carriage of weapons and handcuffs, training requirements and other professional standards. MLEOs in general operate under legislation that regulates their work and authority in the 'public domain' of streets, squares and neighbourhoods. Although, in this way, the initial employment objective accompanying the City Wardens has been abandoned, it is still relevant to the (alleged) poor social image of MLEOs, their social impact and the wish of municipalities to recruit better-trained professionals. Putting these issues in a larger context, we first ask why City Wardens have been turned into 'Special Investigative Officers' (BOAs). What makes MLEOs so popular?

\section{Explaining the rise of MLEOs}

A number of common factors appear to have contributed to the rise of MLEOs in the Netherlands. These include growing concerns about crime and security, the commodification of city centres, the decline of informal social control and the ambition of municipalities to have a greater say in policing and law enforcement strategies (Van Steden and Jones 2010). We discuss each factor in turn below.

A first explanation for the proliferation of MLEOs is the growth of crime and disorder in Dutch cities and towns. Although recorded crime has been falling in the Netherlands since the turn of the millennium, a longer time frame casts a different light on the picture. For example, between the 1960s and 2007, the number of crimes reported to the Dutch police increased tenfold from about 120,000 to 1.2 million cases. Nevertheless, of greater relevance than actual crime victimisation is perhaps the constant subjective awareness of danger (Boutellier 2004). Fear of crime and disorder may be a proxy for a wide array of varied, often unconnected social anxieties, such as dog dirt in the streets, unruly youth, panhandling by homeless people, litter and graffiti. It is exactly these kinds of antisocial behaviour and public nuisance that MLEOs are expected to deal with.

Second, the urban environment is increasingly coming to be dominated by commercial interests, meaning that new strategies of risk management have less to do with concerns about objective crime rates than with the governance of 'commodified' (Loader 1999) public order. Under the banner of 'city marketing', economic rationalities focus on the creation of attractive, consumer-friendly sites that represent both enclaves of freedom and networks of dense regulation. Thus, unsurprisingly, the prominent hosting function of the MLEOs relates to a combination of visible patrolling, propagating a 'clean and safe' rationality and implementing 'anti-nuisance' strategies, while at the same time 
promoting the city as a welcoming, exciting, risk-free space for consumption (cf. Sleiman and Lippert 2010). MLEOs are friendly faces carrying a 'big stick'.

Third, it is plausible to relate current trends in plural policing to an overall decline of informal sources of social control (Jones and Newburn 2002). 'Natural surveillance' exerted by ordinary citizens, churches and neighbourhood groups has been gradually replaced by professionals such as MLEOs whose primary task is to deliver policing and security. This observation relates in part to evaporating 'community' institutions, as highlighted by a range of sociologists in their analyses of the 'disembedding' processes of 'late' or 'post' modernity (e.g., Giddens 1990). Subsequently, there have also been marked public savings on professionals like milkmen, caretakers and railway masters, all of whom once provided low-level controls in addition to their main functions. As Terpstra stresses, during the 1980s and 1990s:

for reasons of cost reduction and financial cutbacks, many jobs which had primarily a service function but which in practice also had an important (informal, secondary) task of control and surveillance, were eliminated or cut back. Workers like caretakers, conductors, platform guards, and wardens in blocks of flats almost disappeared in those years. $(2008$, p. 110)

Arguably, MLEOS and other policing auxiliaries have taken their place, whereby the control of crime and disorder has become a more prominent narrative in the urban domain.

Finally, the rise of MLEOs in the Netherlands can be interpreted as a solution to struggles between locally organised policing on the one hand and the implementation of a centrally led police system on the other hand. Since 1 January 2013, the former 25 police regions with a national constabulary have now been brought together under the umbrella of a single force. Although it is still too early to gain a view of all the consequences of what is currently happening to routine police work, the establishment of a national force seems to be having a negative effect on police officers' engagement with local citizens. This, in turn, leaves open a 'gap' through which MLEOs can enter. Since national government has successfully encouraged local governments to take on more responsibility in the fight against public order problems, mayors are now seeking to deploy their own policing forces (Prins 2014). Relatedly, the empowerment of auxiliary officers such as MLEOs reflects a political climate that favours stricter law enforcement in an age of high workloads for the police and severe pressures on the criminal justice system (Terpstra and Havinga 2005). The idea behind taking plural police agents and agencies on board is thus simply to bring more, and better equipped, surveillance onto the streets. This is not the case in all countries. For example, in Britain (Johnston 2006) and Australia (Cherney and Chui 2010), the implementation of plural policing in urban areas has been primarily about improving community engagement.

\section{The practice and practicalities of municipal policing}

This section delves into the practice and practicalities of municipal policing. It examines the recruitment of MLEOs; discusses their tasks, roles and use of legal powers; highlights their discretionary autonomy; and questions their professional image and social impact. In overall terms, although MLEOs still suffer from the ambiguities and prejudices that clung to the former City Wardens, they are currently rapidly transforming into mature professionals alongside the regular police. 


\section{Recruitment}

The recruitment of MLEOs is generally driven by the wish to employ others than former City Wardens and to dispose of those who do not meet higher educational and training standards. Thus, the recruitment of staff does not now so much anticipate that MLEOs should, for example, be ethnically diverse and truly representative of the communities they serve. Instead, municipal policies to recruit new personnel are primarily geared to shedding the sloppy image that City Wardens have (Van Steden and Bron 2012, Bervoets et al. 2013). MLEOs are now being enrolled internally from various municipal departments (such as tram and metro conductors) and externally from state and market sectors, including the police and the private security industry.

Before BOA powers are conferred on municipal enforcers, they are subject to a criminal background check and intermediate vocational training. MLEOs receive a certificate of good conduct and a basic diploma as proof of their reliability and competence. Nevertheless, further quality improvements have largely been left to the work floor. A direct effect of this is that larger cities have set up prestigious 'academies' to train their staff, while smaller municipalities are lagging behind in the materialisation of professional standards (Mein and Hartman 2013). There are also indications that MLEOs are not paid equally throughout the Netherlands.

\section{Tasks and roles}

A survey of the published ethnographies (Terpstra 2012, Van Steden and Bron 2012, Bervoets et al. 2013, Willemse et al. 2013, Eikenaar and Van Stokkom 2014) reveals that MLEOs perform a number of tasks. First, they patrol and supervise the streets. MLEOs most often do this on foot, but they also make use of bicycles and scooters, and marked cars. In line with mundane policing (e.g. Bayley 1994: chapter 3), their core task is to be visible to the public. Reporting problems, providing a preventive presence and responding to citizens' calls or complaints are key here. Second, MLEOs may intervene in a situation. For example, they can warn unruly youths and correct antisocial behaviour without imposing sanctions on the culprits.

Third, MLEOs have the power to maintain order by issuing fines to offenders and making arrests. Rather than using offensive power, as the police sometimes do, MLEOs only operate in defensive mode: they are able to restrain people who resist their directions or start shouting names at them. Some MLEOs are equipped with handcuffs, a baton and pepper spray. Fourth, MLEOs are uniformed hosts and hostesses who point tourists in the right direction - 'sir/madam, can you show me the route to ...?' (the Van Gogh Museum, the Anne Frank house, the nightlife district in Amsterdam, etc.) - and offer people other friendly advice.

Fifth, MLEOs can be taken as a variation on the 'community building' theme. In particular, within small neighbourhoods and communities, MLEOs gather information from local inhabitants and socialise with them. They take note, for instance, of broken windows, malfunctioning lighting and loose paving slabs. Moreover, MLEOs make contact with maintenance services, active citizens and partners such as schools, local businesses and youth work to solve problems or initiate activities. Their ambition, in short, is to facilitate environmental improvement, empower people to take better control over their communities and forge an interface between the police and other public or private bodies. Sixth, and finally, MLEOs perform administrative duties. They fill in forms and enter information in computer databases. 
Given the categorisation above, it will come as no shock that MLEOs embody very different, and potentially conflicting, roles and tasks. On the one hand, they continue to fulfil the City Wardens' role of being a 'friendly face' on the streets, while, on the other hand, MLEOs try to align themselves with harsher police and law enforcement work. Depending on local circumstances, municipalities tailor their policies towards an emphasis on policing, welfare or hospitality roles, and mixtures of these. MLEOs therefore frequently suffer from 'identity crises' (Van Steden and Bron 2012) about who they are and what their existence means for society. This leaves a lingering uncertainty as to what their ambition and mission may be.

\section{Use of legal powers}

MLEOs derive their powers from Dutch criminal law and administrative law. Originally, these professionals took up the role of parking wardens and were allocated the task of fining car owners for 'fee-dodging' and bad parking habits. To reiterate, today they can also fine people for offences like public drunkenness, littering, loitering, dog fouling and leaving bicycle wrecks unattended. Yet, with the exception of issuing parking fines, Willemse et al. (2013) found that MLEOs in Rotterdam hardly ever use their full powers. MLEOs behave remarkably leniently in their interactions with offenders, even up to the point where they act dissimilarly in equivalent situations. These findings replicate conclusions observers have reached in Amsterdam and elsewhere (Van Steden and Bron 2012, Bervoets et al. 2013). There are two possible explanations for this.

First, MLEOs enjoy a wide 'discretionary space' (Lipsky 1980), that is, it is ultimately up to them to decide whether or not to issue a ticket. MLEOs say they dislike 'ticket quotas', but they may also fear negative reactions from the public. It is quite plausible that many of them still need to adapt to their new professional status. Second, MLEOs think that issuing fines should not be a goal in itself. As in the old days of City Wardens, many of these professionals still perceive themselves in terms of 'hosts', 'stewards' and 'ambassadors', not in terms of 'police' and 'law enforcement'. This distinction resonates with MLEOs' divided opinions about their uniforms. Some municipalities have dressed their MLEOs quite similarly to the police. However, others have distinctively different uniforms, which signals a more accessible attitude to the citizenry. The Dutch Ministry of Safety and Justice is now attempting to impose a standard MLEO uniform style on the municipalities.

\section{Discretionary autonomy}

From their observations, the researchers were especially struck by how boring and dull day-to-day MLEO work can be (Bervoets et al. 2013). Despite their broad occupational range and all the high hopes surrounding them, MLEOs frequently wandered around aimlessly waiting, if not begging, for something to happen (Van Steden and Bron 2012). Specifically, the tremendous autonomy that MLEOs possess must be emphasised here. These findings might be taken positively: MLEOs cannot do without high levels of discretion and responsibility if they are to live up to their full potential as front-line civil servants who have the power to 'mobilise organisational, legal, moral and social resources for a public purpose and, in some cases, can effectively lead members of the community into action' (Vinzant and Crothers 1996, p. 471). Yet, viewed from a pessimistic (and perhaps more realistic) angle, MLEOs are devoid of proper guidance.

Analogous to Reuss-Ianni's (1983) famous book on 'street cops' and 'management cops', MLEOs complain that their bosses have forgotten about them, busy as they are with 
their own career paths. Whether or not this is actually true, respondents in Amsterdam and other municipalities are not always subject to strict supervision (Rekenkamer Rotterdamse 2012, Van Steden and Bron 2012, Bervoets et al. 2013). Many of them are sent to work with only a brief notification (sometimes by telephone or e-mail) from their team leaders about what to do and where to go. That being said, the police remain the most obvious collaborators with the MLEOs on the streets. Nonetheless, and echoing an earlier study of City Wardens, relationships with local police forces differ greatly throughout the Netherlands:

\begin{abstract}
Where schemes are not integrated with the police organisation co-operation can be [...] problematic. [...] [T]he police will accept, work with and 'co-opt' policing agencies whose organisation and operation confirms the police as the dominant partner, but [...] agencies based in another power block (such as the council) can lead to significant competition. (Hofstra and Shapland 1997, p. 274)
\end{abstract}

We shall return to this point when reflecting on how MLEOs may undermine the police's commonly accepted monopoly on matters of public order and law enforcement.

\title{
Professional image
}

The degree to which MLEOs seem to be accepted or, at least, agnostically tolerated in the Netherlands is quite surprising given their frequently assumed poor image as former longterm unemployed and poorly skilled City Wardens. Neither public perception data nor ethnographic evidence confirm popular allegations that MLEOs are merely interested in 'zero-tolerance policing' and that they treat citizens without respect (Van Stokkom 2005). Nor are there grounds for concern that MLEOs would not be very well suited to their tasks and lack proper authority, which may fuel verbal aggression and physical violence against them. Participant observations (Van Steden and Bron 2012, Bervoets et al. 2013) report very few, if any, serious incidents.

Additionally, MLEOs use narratives to try to shape their identity, channel their emotions and build professional pride (cf. Van Hulst 2013). Respondents feel they do important work, contribute positively to their districts in terms of fear of crime and uphold public values (Van Steden and Bron 2012, Bervoets et al. 2013). Others still struggle with what can be described as the 'Calimero effect' (tiny black bird whining: 'I am small, and he [the police, RvS] is big, and that's not fair!'), a metaphor inspired by a Dutch children's television programme (Eikenaar and Van Stokkom 2014). As has become clear, MLEOs have to live with the onerous legacy of City Wardens as a longterm unemployment project. A great deal of job uncertainty, continuous reorganisations and rising occupational standards are also potentially destabilising factors.

\section{Social impact}

It is impossible to accurately gauge the social impact of MLEOs. For example, in an evaluation of 'Flying Squads', a team of MLEOs, police and youth workers in Amsterdam, we concluded that crime and disorder figures were indeed decreasing in the neighbourhoods where these squads were deployed (De Groot and Van Steden 2011). According to the Department of Research and Statistics, data in the three boroughs investigated revealed the following: 
- Red-light district: the objective index dropped from 260 (2003) to 107 (2010) and the subjective index dropped from 168 to (2003) to 107 (2010).

- Transvaal borough: the objective index dropped from 89 (2003) to 75 (2010) and the subjective index dropped from 127 to (2003) to 99 (2010).

- Geuzenveld borough: the objective index dropped from 94 (2003) to 71 (2010) and the subjective index dropped from 114 to (2003) to 102 (2010).

However, this effect can never be isolated from an abundance of other public safety and welfare projects running in the same areas. Moreover, much of the work undertaken by MLEOs is not amenable to quantitative measures at all (a lot of their time is spent walking around and engaging in 'small talk' with, for example, local residents and entrepreneurs), meaning that assessing their impact relies on public perceptions and anecdotal information. Data collected from an online panel (Van Steden and Roelofs 2009) demonstrate that citizens expressed assorted judgements about auxiliary policing. Many were accepting or neutral about private security guards and MLEOs in the public space, but at the same time they lacked a clear idea of their quality and professionalism. Respondents had no outspoken opinions about newcomers in the police extended family.

\section{Reflection}

Taken as a whole, the practice of MLEOs shows that they exemplify a novel manifestation of community policing, one that contests police sovereignty over the maintenance of public order. As Shearing and Marks put it:

police have to be adaptable and think outside of the boxes in which they have placed themselves, $[\ldots]$ and discover who the many actors are that make communities safer places to live in. In doing this they need to think more about where they are not required to be primary actors, and instead to encourage and support other groupings to design and implement safety programmes. (2011, p. 216)

Rather than considering community policing as a much disputed police strategy, we may just as well view it as a product of increasing local security networks and alliances, in which MLEOs are coming to play an increasingly important role. As such, they represent an example of the 'pluralisation' (Loader 2000) or 'multilateralisation' (Bayley and Shearing 2001) of police roles and functions. Despite a few attempts to deliver detailed international comparative overviews of newly emerging auxiliary forces (Jones and Newburn 2006, Terpstra et al. 2013), empirical studies generally show a strong AngloSaxon approach to developments in policing. This section therefore reflects on how plural policing in the Netherlands - especially the rise of MLEOs - relates to the widening policing family, in particular in Britain. It also poses the more fundamental question, which is whether the police will maintain their central position in a fragmenting system of local security governance. Do MLEOs signal the rise of a new municipal police?

As mentioned above, an essential difference between PSCOs in Britain and MLEOs in the Netherlands is that the former are employed by the police forces, while the latter form part of the municipal safety organisation. In fact, PSCOs are more akin to politiesurveillanten (Police Patrollers), who rank lower than ordinary officers but have a higher status than City Wardens (Hofstra and Shapland 1997). Originally, the implementation of Police Patrollers can be seen as a response to the introduction of 
City Wardens throughout the Netherlands. These patrollers, in turn, became an inspiration for setting up PCSOs and various types of wardens in England and Wales (Terpstra et al. 2013). As such, Britain has followed the Netherlands in establishing this 'second tier' of policing (Johnston 2003, p. 189), after which PCSOs turned out to be much more successful than their Dutch counterparts. Police Patrollers are virtually extinct now, thanks to their ambivalent position within the force. Their colleagues never took them seriously as fully fledged officers, a problem that has never been successfully resolved. Yet, international policy transfers still provide strong incentives to shape the rhetoric and reality of assorted auxiliary policing models.

Given that MLEOs (unlike PCSOs) are not well integrated members of the police force, the divisions between municipal quasi-policing and regular state policing remain fluid. The police maintain their task and role in the public domain and are obliged by statute to exercise 'operational direction' (operationale regie) over MLEOs. At the same time, as Mein and Hartman conclude, the practice of police command and control within plural policing operations is limited to:

the joint execution of special enforcement campaigns. Outside this framework, the opportunities for systematic collaboration between Special Investigating Officers and the police remain insufficiently utilised. (2013, p. 77)

This conclusion resonates in all reports and papers on MLEOs published so far (Rekenkamer Rotterdamse 2012, Terpstra 2012, Van Steden and Bron 2012, Bervoets et al. 2013, Eikenaar and van Stokkom 2014). The only exceptions are restricted briefings and debriefings organised in several police stations in the larger cities to inform individual MLEOs and wider groups of auxiliary officers about, for example, criminal offences, suspects and 'hot spots'. In other words: in contrast to PSCOs, who should 'keep the family together' (Johnston 2007), MLEOs contribute to an ongoing fragmentation of Dutch security governance.

Municipal policy-makers and politicians, for their part, are reluctant to accept an overly vigorous involvement of the police in guiding MLEOs, cherishing them rather as their own security personnel. Not unexpectedly, therefore, partnership building primarily takes the form of internal - municipal - collaborations that MLEOs seek with, for example, youth workers and street coaches. In particular, within smaller communities and neighbourhoods, there is good potential for integrated initiatives (Bervoets et al. 2013). Nevertheless, desires to create closely knit networks of policing and security delivery at the local level leave unresolved strategic dilemmas about how to organise such forms of collaboration. This brings us back to the future of Dutch policing. Will the fragmentation process proceed, and will there be a more important role for municipalities in policing to the detriment of the police's traditional coordinating task?

There are currently significant developments in the Netherlands that assume an equal positioning as between police officers and MLEOs. Local governments are increasingly gaining a pivotal role in the field of plural policing. By neglecting their classical patrol functions, the police may partly have themselves to blame for the situation in which they now find themselves. Simultaneously, there is truth in the argument that municipalities and their mayors, who transcend the boundaries between organisations (cf. Prins 2014), are better suited to coordinate broad security networks, including plural policing initiatives. This means, as Terpstra et al. write, that local authorities acquire an 'enforcement arm' - that is to say: 
[b]y having their own municipal enforcement guards with sanctioning powers, local governments can use coercive means in the management of social disorder and (petty) crime, without depending on the police. (2013, p. 155)

Whether the Netherlands will actually go down the route sketched here is a moot point. A vital challenge is still the (in)ability of MLEOs to break with their past. If they are able to shed their history of subsidised job creation, and all problems resulting from this - a poor social image, an unstable identity, inadequate skills and so on - they are likely to strengthen their position going forward.

\section{Conclusions}

This article has centred on explaining the growing popularity of MLEOs in the Netherlands; describing their practices and practicalities; and discussing their (assumed) impact on the police as the key player in Dutch security governance. In answer to the questions raised, it is critical to recall that MLEOs are an evolution of the earlier City Wardens, who were enrolled in a re-employment programme (Hauber et al. 1996, Hofstra and Shapland 1997). What started as municipal employees devoid of any special powers has developed into the appointment of police-like staff who are mandated to issue on-thespot fines for relatively minor offences like public urination, public drunkenness and other forms of nuisance.

Several factors are driving this trend. Against the background of rising crime and (feelings of) insecurity, the commodification of city centres and worries about the lack of social control in anonymous urban spaces, the Dutch central government has 'responsibilised' (Garland 1996) local authorities to address problems of crime and disorder. Municipalities and mayors have set up local auxiliary policing schemes partly because of a more 'law-and-order' orientation to the political debate and partly because of the withdrawal of police officers from community-oriented tasks (e.g., patrolling and maintaining close contacts with the citizenry).

However, the emergence of MLEOs in cities and towns has been fraught with tension. Such officers are often confronted with contradictory expectations, leading them to incline towards either a 'narrow' - regulatory law enforcement - role or a 'wide' socially oriented ambassador - orientation (cf. Millie 2013), which therefore induces them to search for a grounded identity. Moreover, a lack of managerial direction is difficult to reconcile with the MLEOs' demand for focus, while they have trouble gaining the trust of both the professionals (police and street corner workers) and citizens, not least youngsters. Current criticisms of the MLEOs' indeterminate roles and tasks, their controversial image and their underspecified social impact thus need to be convincingly countered if they are to achieve a more mature status within the Dutch police extended family.

If MLEOs succeed in doing this (and the prospects are not necessarily bleak), they have the opportunity to become a restyled type of community police officer. Not inconceivably, this scenario may even further encourage the police to abandon the elementary patrolling tasks and responsibilities on the streets. Following Terpstra et al::

[i]n the Netherlands it is currently not unusual to speak about 'the new municipal police', which is quite ironic if one realises that the police reform of 1993 (which paved the way for the 2013 police reform) abolished the municipal police forces. 
Over a longer period of time, it appears that the Dutch national government's creeping aspirations towards the centralisation of public policing will possibly simply rebound, biting its own tail as a result.

\section{Disclosure statement}

No potential conflict of interest was reported by the author.

\section{References}

Ayling, J., Grabosky, P., and Shearing, C., 2009. Lengthening the arm of the law: enhancing police resources in the twenty-first century. Cambridge: Cambridge University Press.

Bayley, D., 1994. Police for the future. Oxford: Oxford University Press.

Bayley, D., and Shearing, C., 2001. The new structure of policing: description, conceptualization, and research agenda. Washington, DC: National Institute of Justice.

Bervoets, E., Bik, J., and De Groot, M., 2013. Gemeentelijk blauw: het dagelijks werk van gemeentelijke handhavers in beeld [Municipal blue: portraying the daily work of municipal law enforcers]. Amsterdam: Reed Business.

Boutellier, J., 2004. The safety utopia: contemporary discontent and desire as to crime and punishment. Dordrecht: Kluwer Academic.

Buerger, M., and Mazerolle, L., 1998. Third-party policing: a theoretical analysis of an emerging trend. Justice quarterly, 15 (2), 301-327.

Cherney, A., and Chui, W.H., 2010. Police auxiliaries in Australia: police liaison officers and the dilemmas of being part of the police extended family. Policing and society, 20 (3), 280-297.

Cohen, L.E., and Felson, M., 1979. Social change and crime rate trends: a routine activity approach. American sociological review, 44 (4), 588-608.

Crawford, A., et al., 2005. Plural policing: the mixed economy of visible patrols in England and Wales. Bristol: Policy Press.

De Groot, I., and Van Steden, R., 2011. De praktijk van Vliegende Brigades: doelen, werkprocessen en opbrengsten [The practice of flying squads: goals, processes and outcomes]. Amsterdam/Den Haag: Vrije Universiteit/Nicis Institute.

Donnelly, D., 2008. Community wardens in Scotland: practitioners' views. The Howard journal, 47 (4), 371-382.

Eikenaar, T., and Van Stokkom, B., 2014. Stadswacht of gemeentepolitie? Gemeentelijk toezicht en handhaving in de openbare ruimte [City warden or municipal police? Municipal law enforcement in the public domain]. Nijmegen: Radboud University. Draft Report for the Police Science and Research Program, Police Academy Apeldoorn.

Garland, D., 1996. The limits of the sovereign state: strategies of crime control in contemporary society. British journal of criminology, 36 (4), 445-471.

Giddens, A., 1990. The consequences of modernity. Stanford, CA: Stanford University Press.

Hauber, A., et al., 1996. Some new forms of functional social control in the Netherlands and their effects. British journal of criminology, 36 (2), 199-219.

Hofstra, B., and Shapland, J., 1997. Who is in control? Policing and society, 6 (4), 265-281.

Jason-Lloyd, L., 2003. Quasi-policing. London: Cavendish.

Johnston, L., 2003. From 'pluralisation' to 'the police extended family': discourses on the governance of community policing in Britain. International journal of the sociology of law, 31 (3), 185-204.

Johnston, L., 2005. From 'community' to 'neighbourhood' policing: police community support officers and the 'police extended family' in London. Journal of community \& applied social psychology, 15 (3), 241-254.

Johnston, L., 2006. Diversifying police recruitment? The deployment of police community support officers in London. The Howard journal, 45 (4), 388-402.

Johnston, L., 2007. 'Keeping the family together: community support officers and the "police extended family' in London. Policing \& society, 17 (2), 119-140.

Johnston, L., and Shearing, C., 2003. Governing security: explorations in policing and justice. London: Routledge. 
Jones, T., and Newburn, T., 2002. The transformation of policing? Understanding current trends in policing systems. British journal of criminology, 42 (1), 129-146.

Jones, T., and Newburn, T., eds., 2006. Plural policing: a comparative perspective. London: Routledge.

Lipsky, M., 1980. Street-level bureaucracy: dilemmas of the individual in public services. New York, NY: Russell Sage Foundation.

Loader, I., 1999. Consumer culture and the commodification of policing and security. Sociology, 33 (2), 373-392.

Loader, I., 2000. Plural policing and democratic governance. Social and legal studies, 9 (3), 323-345.

Manning, P., 2005. The study of policing. Police quarterly, 8 (1), 23-43.

McLaughlin, E., 2007. The new policing. London: Sage.

Mein, A., and Hartman, A., 2013. De stand van het boa-bestel: eindrapportage over het stelsel waarbinnen buitengewoon opsporingsambtenaren functioneren [The status of the special investigation system: final report on the system in which special investigating officers operate]. Utrecht: Verwey-Jonker Institute.

Merritt, J., 2009. Pluralist models of policing: legislating for police powers, a cautionary note from England and Wales. Policing: a journal of police strategies \& management, 32 (2), 377-394.

Millie, A., 2013. The policing task and the expansion (and contraction) of British policing. Criminology and criminal justice, 13 (2), 143-160.

Noaks, L., 2000. Private cops on the block: a review of the role of private security in residential areas. Policing \& society, 10 (2), 143-161.

Prins, R., 2014. Safety first: how local processes of securitization have affected the position and role of Dutch mayors. The Hague: Eleven International.

Rekenkamer Rotterdam, 2012. Horen, zien en schrijven: optreden van stadswachten in de openbare ruimte [Hearing, seeing and fining: the practice of city wardens in the public domain]. Government report. Rotterdam: Municipality of Rotterdam.

Reuss-Ianni, E., 1983. Two cultures of policing: street cops and management cops. New Brunswick, NJ: Transaction.

Shearing, C., and Marks, M., 2011. Being a new police in the liquid 21st century. Policing: a journal of policy and practice, 5 (3), 210-218.

Sleiman, M., and Lippert, R., 2010. Downtown ambassadors, police relations and 'clean and safe' security. Policing \& society, 20 (3), 316-335.

Terpstra, J., 2008. New security patrols in public spaces: reassurance, fragmentation, and marketization. In: M. Easton, L. Gunther Moor, B. Hoogenboom, P. Ponsaers and B. van Stokkom, eds. Reflections on reassurance policing in the low countries. Den Haag: Boom Juridische Uitgeverij, 105-126.

Terpstra, J., 2012. Particuliere beveiligers als publieke handhavers: de inzet van private boa's door gemeenten [Private security officers as public enforcers: the use of private boas by municipal councils]. Justitiële Verkenningen, 38 (8), 35-50.

Terpstra, J., and Havinga, T., 2005. Gemeenten, boetes en kleine ergernissen [Councils, fines and nuisances]. Justitiële Verkenningen, 31 (6), 10-22.

Terpstra, J., Van Stokkom, B., and Speeuwers, R., 2013. Who patrols the streets? The Hague: Eleven International.

Van Andel, H., 1989. Crime prevention that works: the case of public transport in the Netherlands. British journal of criminology, 29 (1), 47-70.

Van Hulst, M., 2013. Storytelling at the police station: the canteen culture revisited. British journal of criminology, 53 (4), 624-642.

Van Steden, 2012. Veelvormig en versnipperd: gemeentelijke toezichthouders en handhavers in het publieke domein [Multifaceted and fragmented: municipal law enforcement officers in the public domain]. Amsterdam/The Hague: Vrije Universiteit/SMVP.

Van Steden, R., and Bron, E., 2012. Gemeentelijke handhavers in Amsterdam: een onderzoek naar hun werk op straat [Municipal law enforcers in Amsterdam: depicting their work on the streets]. Den Haag: Boom-Lemma.

Van Steden, R., and Jones, T., 2010. Explaining the growth of plural policing: comparing the Netherlands and Britain. Journal of Police Studies, 16 (3), 289-306. 
Van Steden, R., and Roelofs, M., 2009. Hoeders van de hygiënische stad: beveiligers, toezichthouders en handhavers in de openbare ruimte [Guardians of a hygienic city: security officers and city supervisors in the urban public domain]. B en M, Tijdschrift voor Beleid, Politiek en Maatschappij, 36 (3), 157-169.

Van Stokkom, B., 2005. Zero-tolerance in de praktijk: handhaving van de 'kleine norm' door politie of boa's? [Zero-tolerance in practice: maintaining the 'minor norms' by the police or special enforcement teams?]. Justitiële Verkenningen, 31 (6), 44-59.

Vinzant, J., and Crothers, L., 1996. Street-level leadership: rethinking the role of public servants in contemporary governance. The American review of public administration, 26 (4), 457-476.

Willemse, R., Dickson, S., and De Waijer, C., 2013. De stadswacht als frontlijnambtenaar: participerend onderzoek naar het optreden van Rotterdamse stadswachten in de openbare ruimte [The city warden as front-line worker: participatory research on the practice of Rotterdam city wardens in the public domain]. Tijdschrift voor Toezicht, 4 (2), 27-42. 